\title{
Knudsen Cell-mass Spectrometric Study of the Thermodynamic Properties of Fe-Mo Alloys*
}

\author{
By Eiji ICHISE,** Toshiaki MARUO,*** Hiroyasu SASHO,**** \\ Yoshiyuki UESHIMA ${ }^{* * * * *}$ and Toshisada MORI**
}

\section{Synopsis}

A technique of Knudsen cell-mass spectrometric determination of activity of iron-refractory metal alloys was devised. The technique consists of the measurement of ion intensity of internal standard material, $\mathrm{Fe}$ or $\mathrm{Ag}$, at lower temperature and the measurement of ion intensity of $\mathrm{Fe}$ from the sample at experimental temperature. This technique was applied to $\mathrm{Fe}-\mathrm{Mo}$ alloys to determine the activities over the entire composition range at $1823 \mathrm{~K}$.

The activity curves are determined over the entire composition range at $1823 \mathrm{~K}$. The following values were obtained.

$$
\gamma_{\mathrm{Mo}}^{\circ}(s)=1.54, \gamma_{\mathrm{Mo}_{0}}^{\circ}(l)=0.7 \text { and } \gamma_{\mathrm{Fe}}^{\circ}(l)=6.0
$$

Interaction parameters were also determined.

The free energy change for the reaction

Mo $(s)=\underline{\text { Mo }}$ (hypothetical Henrian 1 wt $\%$ in liquid $\mathrm{Fe}$ )

is given by

$$
\Delta G^{\circ}=27100-54.1 T \mathrm{~J} / \mathrm{g} \text {-atom. }
$$

The heat of sublimation of $\delta$-Fe was also determined from the ion intensities at $A_{4}$ and m.p. temperatures.

The heat of sublimation and melting of $\mathrm{Fe}$ are

$$
\Delta H^{s}(\alpha)_{298}=414 \mathrm{~kJ} / \mathrm{g} \text {-atom }
$$

and

$$
\Delta H_{1809}^{m}=15.1 \mathrm{~kJ} / \mathrm{g} \text {-atom }
$$

\section{Introduction}

Little has been known about the thermodynamic behavior of $\mathrm{Fe}-\mathrm{Mo}$ alloys at high temperatures. Only a calorimetric measurement on the heat of mixing at low Mo concentration in liquid Fe-Mo alloys ${ }^{1)}$ and a theoretical evaluation of the activity coefficients of components from the interaction energies $^{2)}$ have been reported. In this study, activities in $\mathrm{Fe}-\mathrm{Mo}$ alloys over the entire composition range have been measured at $1823 \mathrm{~K}$ by the use of the Knudsen cell-mass spectrometry.

In Knudsen cell-mass spectrometric measurements, the following equation holds between the partial pressure $P_{i}$ of the species $i$ in the Knudsen cell at temperature $T(\mathrm{~K})$ and the ion intensity $I_{i}^{+}$.

$$
P_{i}=k I_{i}^{+} T / \eta_{i} \sigma_{i} \beta_{i}
$$

where $k$ is an apparatus constant including geometric relation between the cell and the ion source, $\eta_{i}$ is the isotopic abundance, $\sigma_{i}$ is the ionization cross section and $\beta_{i}$ is the sensitivity of the ion detector. In order to determine $P_{i}$ according to Eq. (1), it is necessary to know the value for $k$. Unfortunately, the value for $k$ may vary from run to run and is difficult to determine experimentally or theoretically.

However, in determination of activities, there are several methods to eliminate determination or consideration of $k$. These are measurements of ion intensity for alloys followed by measurements of ion intensity for the pure component of the alloy under the condition that $k$ remains constant, ${ }^{3)}$ double Knudsen cell method, ${ }^{4)}$ triple chamber Knudsen cell method,5) ion intensity ratio method, ${ }^{6)}$ internal standard method $\left.^{6}\right)$ where an inert standard material is charged in the cell containing alloy or pure material to be studied and both of these ion intensities are measured simultaneously, and the modified GibbsDuhem method. ${ }^{7)}$ The modified Gibbs-Duhem method has been used extensively in the investigation of iron based alloys. Though this method is powerful, it can be applied only to alloy systems in which all components of the alloy have appropriate detectable vapor pressures over the entire concentration range. This method is not applicable in the case of the FeMo alloy at the steelmaking temperature, since Mo has very low vapor pressure, about $3 \times 10^{-10}$ atm even at $2000 \mathrm{~K}$. For this reason, a technique applicable to systems of this type was devised.

The method developed is in principle, a modified internal standard method. This method is composed of the measurement of ion intensity of a standard component at lower temperature and the measurement of ion intensity of the component of alloy at desired temperature. Solid pure iron was used as the standard material for alloys of such composition that the alloy forms uniform liquid at experimental temperature range. Silver was used as the standard material for alloys other than the alloy which forms uniform liquid solution. Though this method is not simultaneous measurement, the results showed that this method could yield good measurements. Saito et al. ${ }^{8)}$ used $\mathrm{Pb}$ as the standard material in order to determine the dissociation constant of phosphorus gas over $\mathrm{Fe}-\mathrm{P}$ alloy, but their method is different from that of the present study in that they utilized values

\footnotetext{
* Originally published in Tetsu-to-Hagané, 66 (1980), 1075, in Japanese. English version received May 28, 1981. (C) 1982 ISIJ

** Department of Metallurgy, Faculty of Engineering, Kyoto University, Yoshida-honmachi, Sakyo-ku, Kyoto 606.

*** Formerly Graduate School, Kyoto University. Now at Muroran Plant, The Japan Steel Works Ltd., Chatsumachi, Muroran 051.

**** Formerly Graduate School, Kyoto University. Now at Yasuda Tekkosho Ltd., Naraihara, Kamogawa 296-01.

***** Formerly Graduate School, Kyoto University. Now at Yawata Works, Nippon Steel Corporation, Yawatahigashi-ku, Kitakyushu 805 .
} 
for $\sigma, \beta$ and $\eta$ obtained from references or calculated under suitable assumptions to calculate the vapor pressures.

In addition, the heat of vaporization of $\delta$-Fe and liquid iron have been determined from the values of the ion intensity of iron at the $A_{4}$ transformation point and the melting point.

\section{Experimental}

\section{Experimental Apparatus}

The HITACHI RM6K Knudsen cell-mass spectrometer assembly was used. The details of the apparatus was already reported.9,10) Sintered alumina crusible of $9 \mathrm{~mm}$ in innerdiameter and $11 \mathrm{~mm}$ in height and lid with orifice of $0.5 \mathrm{~mm}$ in diameter were used as the Knudsen cell.

\section{Samples}

Alloys were prepared from iron of $0.002 \% \mathrm{C}$, $<0.005 \% \mathrm{Si},<0.001 \% \mathrm{Mn}, 0.005 \% \mathrm{P}, 0.005 \% \mathrm{~S}$, $0.005 \% \mathrm{Cu}, 0.004 \% \mathrm{Ni}, 0.003 \% \mathrm{Cr}, 0.013 \% \mathrm{Co}$, $0.003 \% \mathrm{Ti}, \quad<0.001 \% \mathrm{~V}, \quad 0.003 \% \mathrm{Al}, \quad 0.0042 \% \mathrm{O}$ and $0.0017 \% \mathrm{~N}$ and Mo of $99.97 \%$. In case of low Mo alloys, pure component metals were melted, in situ, in a Knudsen cell while the ion intensity of iron was measured. In case of high Mo alloys, samples were prepared in a vacuum arc furnace or in a levitation furnace. The weight of samples was $2 \sim 3 \mathrm{~g}$ for every run. In case of run with alloy melted in situ in the Knudsen cell, the composition of sample was calculated from the charged weights because the difference in the weight before and after the experiment was within several milligrams. As to the premelted alloys, the concentration of Mo was analyzed by the atomic absorption method. The analysis was based on JIS G1257-1975. It was confirmed that when the concentration of $\mathrm{Fe}$ in the solution was kept constant, the absorption curve for Mo held the linearity up to about $50 \mu \mathrm{g} \mathrm{Mo} / \mathrm{ml}$. Fe solution was added to each sample solution to keep the concentration of $\mathrm{Fe}$ in the solution at about $50 \mu \mathrm{g} / \mathrm{ml}$. Each alloy was analyzed four times. The standard deviation of analysis was $\pm 0.5 \%$.

\section{Determination of the Heat of Sublimation and Vaporiza- tion of Iron}

On the continuous heating or cooling of pure Fe, $A_{4}$ transformation, melting and freezing can be confirmed through the arrest and recovery of the ion intensity change of Fe. An example of these phenomena is shown in Fig. 1.

The molecular beam which is analyzed in the Knudsen cell-mass spectrometry comes mainly from the area of the surface of metal seen through the orifice. Therefore the constant ion intensity observed is attributable to the molecular beam emanating from a part of the metal surface where the temperature is exactly at the transformation temperature. Temperatures of the transformations are known with high reliability; therefore, we can correlate the ion intensity at the transformation to the temperature of the trans-

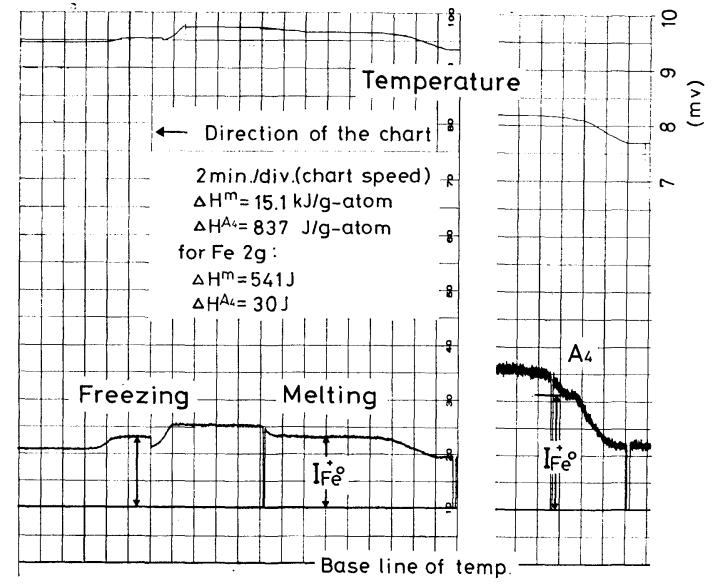

Fig. 1. Change in ion intensity of $\mathrm{Fe}$ on $A_{4}$ transformation, melting and freezing.

formation irrespective of the temperature measured outside of the cell.

From Eq. (1) and the Gibbs-Helmholtz equation we have,

$$
\begin{aligned}
\Delta H & =-R d\left(\ln P_{\mathrm{Fe}}\right) / d(1 / T) \\
& =-R d\left\{\ln \left(I_{\mathrm{Fe}}^{+} \cdot T\right)\right\} / d(1 / T)
\end{aligned}
$$

Assuming a constant heat of sublimation, we have the following equation.

$$
\begin{aligned}
\Delta H^{s}(\delta)= & 2.303 R\left\{\log \left(I_{\mathrm{Fe}}^{+}(m) \cdot 1809\right)\right. \\
& \left.-\log \left(I_{\mathrm{Fe}}^{+}\left(A_{4}\right) \cdot 1665\right)\right\} /(1 / 1665-1 / 1809)
\end{aligned}
$$

where, $\Delta H^{s}(\delta)$ : the heat of sublimation of $\delta-\mathrm{Fe}$

$I_{\mathrm{Fe}}^{+}(m)$ : ion intensity observed on melting or freezing (1 $809 \mathrm{~K}$ )

$I_{\mathrm{Fe}}^{+}\left(A_{4}\right)$ : ion intensity observed on $A_{4}$ transformation ( $1665 \mathrm{~K}$ ).

The value of heat of sublimation calculated in this manner is free from errors in the temperature measurements.

The heat of vaporization of liquid iron was determined from the slope of the $\log (I T)$ vs. $1 / T$ plots.

\section{Determination of Activity}

The activity of $\mathrm{Fe}$ in $\mathrm{Fe}-\mathrm{Mo}$ alloys was determined experimentally and then the activity of Mo was calculated by integrating the Gibbs-Duhem equation.

In order to determine the activity of $\mathrm{Fe}$ in the alloy, one of the following two methods was used depending on the alloy composition.

1. Low Mo Alloys (Atomic Fraction of Mo, $\boldsymbol{x}_{\mathrm{Mo}}<\mathbf{0 . 3 5}$ )

Pure components of desired amount were charged into the cell, Mo in the bottom and Fe over the Mo as shown in Fig. 2. The cell was then heated and the ion intensity of $\mathrm{Fe}$ was measured. Up to near the melting point of $\mathrm{Fe}$, the measured ion intensity can be attributed to the pure solid Fe because the alloying of $\mathrm{Fe}$ and Mo does not take place substantially within this temperature range and only the surface of pure Fe disk faces to the orifice. Ion intensity of pure solid Fe was measured at several temperatures be- 
tween $1570 \mathrm{~K}$ and $1720 \mathrm{~K}$. Then the temperature was raised to melt the charge. After the melting of Fe, alloying took place and a uniform alloy was obtained within 1 to $1.5 \mathrm{hr}$. This was confirmed by the stabilization of ion intensity at a constant temperature. Hereafter, the measured ion intensity of $\mathrm{Fe}$ is attributable to the liquid Fe-Mo alloy and is designated as $I_{\mathrm{Fe}}^{+}$(alloy). From the ion intensities for solid pure $\mathrm{Fe}$, assuming a linear relation between $\log$ $\left(I_{\mathrm{Fe}}^{+} T\right)$ and $1 / T$, and using the heats of sublimation and vaporization of $\mathrm{Fe}$, the value for the ion intensity of pure liquid $\mathrm{Fe}$ from the same cell for the alloy can be calculated. That is, a straight line with slope corresponding to a value of $392 \mathrm{~kJ} / \mathrm{g}$-atom for the heat of sublimation determined by this work was drawn through the experimental points obtained for pure solid $\mathrm{Fe}$ and extended up to the melting point of Fe. There is $A_{4}$ transformation within this temperature range but the change in the slope at $A_{4}$ point can be neglected because the heat of $A_{4}$ transformation, $837 \mathrm{~J} / \mathrm{g}$-atom, ${ }^{11)}$ is less than $0.3 \%$ of the heat of sublimation.

Above the melting point of $\mathrm{Fe}$, another straight line with a slope corresponding to a value of $377 \mathrm{~kJ} / \mathrm{g}$ atom for the heat of vaporization of $\mathrm{Fe}$ was drawn. Thus one can obtain the value for the ion intensity of pure liquid Fe comparable with the ion intensity of $\mathrm{Fe}$ from the alloy. The ion intensity for pure $\mathrm{Fe}$ thus obtained is designated as $I_{\mathrm{Fe}}^{+}$(extrapolated).

The partial pressure of Fe over the alloy, $P_{\mathrm{Fe}}$ (alloy), at temperature $T$ is given by

$$
P_{\mathrm{Fe}}(\text { alloy })=k I_{\mathrm{Fe}}^{+}(\text {alloy }) T / \eta_{\mathrm{Fe}} \sigma_{\mathrm{Fe}} \beta_{\mathrm{Fe}}
$$

The vapor pressure of pure $\mathrm{Fe}, P_{\mathrm{Fe} e}^{\circ}$, at the same temperature $\mathcal{T}$ is given by using the same $k$ by

$$
P_{\mathrm{Fe}}^{\circ}=k I_{\mathrm{Fe}^{\circ}}^{+} \text {(extrapolated) } T / \eta_{\mathrm{Fe}} \sigma_{\mathrm{Fe}} \beta_{\mathrm{Fe}}
$$

The activity of $\mathrm{Fe}, a_{\mathrm{Fe}}$, in the alloy is given by

$$
a_{\mathrm{Fe}} \equiv P_{\mathrm{Fe}}(\text { alloy }) / P_{\mathrm{Fe}}^{\circ}=I_{\mathrm{Fe}}^{+}(\text {alloy }) / I_{\mathrm{Fe}^{\circ}}^{+}(\text {extrapolated })
$$

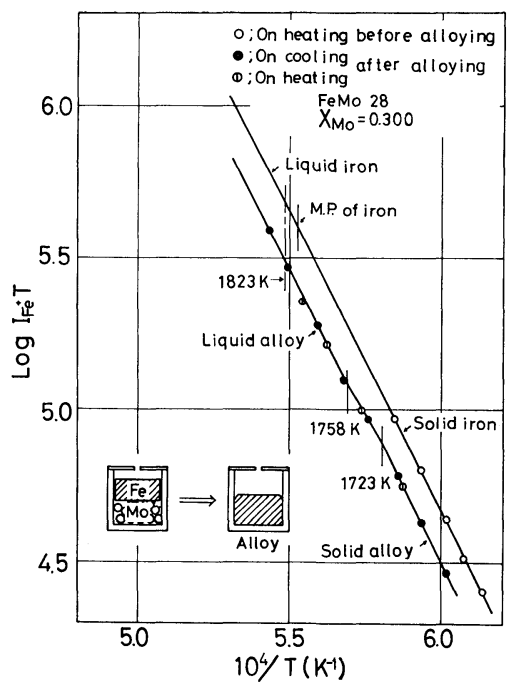

Fig. 2. Procedure for the determination of the activity of $\mathrm{Fe}$ in low Mo concentration range.
A schematic explanation of this calculation is given in Fig. 2. Experiments performed by this method are called Fe-Mo run.

2. High Mo Alloy $\left(x_{\mathrm{Mo}_{\mathrm{o}}}>0.35\right)$

As alloys with Mo concentration $x_{\mathrm{Mo}}>0.35$ have solid phases over the experimental temperature range, it is difficult to obtain a homogeneous alloy sample by the above stated method. In this case, samples were prepared by melting in an arc furnace or levitation furnace. The method of activity determination consists of two types of measurement, one for pure $\mathrm{Fe}$ and the other for alloy. The data from these measurements were compared to yield activity on the reference of ion intensities of $\mathrm{Ag}$ which was placed together with alloy or pure $\mathrm{Fe}$ in the cell in both types of measurement. The run for pure $\mathrm{Fe}$ was performed as follows. As shown in Fig. 3, a pure Fe disk was charged in the cell and a thin Ag. foil weighing about $10 \mathrm{mg}$ was placed on the iron disk so as to cover the whole cross sectional area of the cell. The ion intensity of $\mathrm{Ag}, I_{\mathrm{Ag}}^{+}$was measured at several temperatures up to the melting point of Ag. The temperature was then raised up to the experimental range and the ion intensity of $\mathrm{Fe}, I_{\mathrm{Fe}}^{+}$was measured. This measurement will be called as $\mathrm{Ag}-\mathrm{Fe}$ run.

It was confirmed that the ratio of $I_{\mathrm{Ag}}^{+}$at a certain temperature $T_{\mathrm{Ag}}$ within the temperature range for $\mathrm{Ag}$ measurement to $I_{\mathrm{Fe}^{\circ}}^{+}$at a temperature $(=1823 \mathrm{~K}$ ) is almost constant for runs with different cells as shown later:

$$
I_{\mathrm{Fe}^{\circ}}^{+} / I_{\mathrm{Ag}}^{+}=\lambda=\mathrm{constant}
$$

The same procedure was used in the measurements for alloy. The measurement of this type for alloy will be called as $\mathrm{Ag}-\mathrm{Fe}-\mathrm{Mo}$ run. Ion intensities for $\mathrm{Ag}$ at $T_{\mathrm{Ag}}$ and $\mathrm{Fe}$ at $T_{\mathrm{Fe}}$ in the $\mathrm{Ag}-\mathrm{Fe}-\mathrm{Mo}$ run are designated as $I_{\mathbf{A g}}^{+\prime}$ and $I_{\mathrm{F}_{\theta}}^{+}$(alloy), respectively.

The activity of $\mathrm{Fe}, a_{\mathrm{Fe}}$ can be calculated by the following equation.

$$
a_{\mathrm{Fe}} \equiv P_{\mathrm{Fe}}(\text { alloy }) / P_{\mathrm{Fe}}^{\circ}=\frac{P_{\mathrm{Fe}}(\text { alloy }) / P_{\mathrm{Ag}}}{P_{\mathrm{Fe}}^{\circ} / P_{\mathrm{Ag}}}
$$

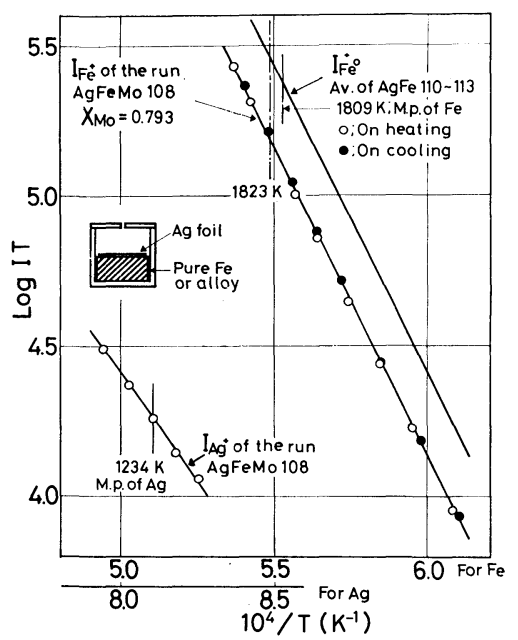

Fig. 3. Procedure for the determination of the activity of $\mathrm{Fe}$ by using $\mathrm{Ag}$ standard in high Mo concentration range. 
where $P_{\mathrm{Ag}}$ is vapor pressure of $\mathrm{Ag}$ at $\mathcal{T}_{\mathrm{Ag}}$. From the Eq. (1) we have,

$$
\begin{aligned}
a_{\mathrm{Fe}} & =\frac{\left(\frac{k^{\prime} I_{\mathrm{Fe}}^{+}(\text {alloy }) T_{\mathrm{Fe}}}{\eta_{\mathrm{Fe}} \sigma_{\mathrm{Fe}} \beta_{\mathrm{Fe}}}\right) /\left(\frac{k^{\prime} I_{\mathrm{Ag}}^{+\prime} T_{\mathrm{Ag}}}{\eta_{\mathrm{Ag}} \sigma_{\mathrm{Ag}} \beta_{\mathrm{Ag}}}\right)}{\left(\frac{k I_{\mathrm{Fe}}^{+} T_{\mathrm{Fe}}}{\eta_{\mathrm{Fe}} \sigma_{\mathrm{Fe}} \beta_{\mathrm{Fe}}}\right) /\left(\frac{k I_{\mathrm{Ag}}^{+} T_{\mathrm{Ag}}}{\eta_{\mathrm{Ag}} \sigma_{\mathrm{Ag}} \beta_{\mathrm{Ag}}}\right)} \\
= & \frac{I_{\mathrm{Fe}}^{+} / I_{\mathrm{Ag}}^{+\prime}}{I_{\mathrm{Fe}}^{+} / I_{\mathrm{Ag}}^{+}} \quad \ldots \ldots \ldots \ldots \ldots \ldots \ldots \ldots \ldots \ldots \ldots \ldots \ldots \ldots \ldots
\end{aligned}
$$

In order to make obvious that $k$-value is different for $\mathrm{Ag}-\mathrm{Fe}$ run and $\mathrm{Ag}-\mathrm{Fe}-\mathrm{Mo}$ run, $k$ and $k^{\prime}$ were used in Eq. (9). Substituting Eq. (7) into Eq. (9), we have,

$$
a_{\mathrm{Fe}}=\frac{I_{\mathrm{Fe}}^{+}(\text {alloy }) / I_{\mathrm{Ag}}^{+\prime}}{\lambda}
$$

\section{Experimental Results}

1. Heat of Sublimation of $\delta-\mathrm{Fe}, \Delta H^{s}(\delta)$ and Heat of Vaporization of Liquid $\mathrm{Fe}, \Delta H^{v}$

Thirty values for $\Delta H^{s}(\delta)$ and six values for $\Delta H^{v}$ were obtained from twelve runs for pure Fe. Mean values of the heats and the standard deviations were as follows.

$$
\begin{aligned}
& \Delta H^{s}(\delta)= 392.0 \pm 0.8 \mathrm{~kJ} / \mathrm{g} \text {-atom } \mathrm{Fe} \\
&= 93.7 \pm 0.2 \mathrm{kcal} / \mathrm{g} \text {-atom Fe } \\
&(1665 \sim 1809 \mathrm{~K}, \text { mean }) \\
& \Delta H^{v}=377.0 \pm 1.0 \mathrm{~kJ} / \mathrm{g} \text {-atom Fe } \\
&=90.1 \pm 0.2 \mathrm{kcal} / \mathrm{g} \text {-atom Fe } \\
&(1809 \sim 1873 \mathrm{~K}, \text { mean })
\end{aligned}
$$

The heat of melting $\Delta H^{m}$ was calculated as the difference of heats of sublimation and vaporization.

$$
\begin{gathered}
\Delta H^{m}=15.1 \pm 1.7 \mathrm{~kJ} / \mathrm{g} \text {-atom } \mathrm{Fe} \\
=3.6 \pm 0.4 \mathrm{kcal} / \mathrm{g} \text {-atom Fe } \\
(1809 \mathrm{~K})
\end{gathered}
$$

\section{Activities in Fe-Mo Alloys}

For the determination of the activity of $\mathrm{Fe}$ in high Mo alloys, it is necessary that $\lambda$ in Eq. (7) maintains a constant value. Runs for high Mo alloy were divided into four groups according to the heating condition, that is, the temperature gradient in $\mathrm{Ta}$ cell holder and the chosen value for $T_{\text {Ag }}$. In each group, $\mathrm{Ag}-\mathrm{Fe}$ runs were repeated between the $\mathrm{Ag}-\mathrm{Fe}-\mathrm{Mo}$ runs. The values for $\lambda$ in each group are shown in Table 1.

The results of the activity measurements for the

\begin{tabular}{|c|c|c|c|c|c|}
\hline \multicolumn{2}{|l|}{ No. } & $\lambda$ & $\begin{array}{c}\bar{\lambda} \\
\text { (mean value) }\end{array}$ & $\begin{array}{l}\text { Run No. } \\
\text { which } \lambda \text { is }\end{array}$ & $\begin{array}{l}\text { in } \\
\text { used }\end{array}$ \\
\hline $\mathrm{Ag}-\mathrm{Fe}$ & 1 & 6.67 & \multirow{2}{*}{6.92} & \multirow{2}{*}{$\begin{array}{c}\mathrm{Ag}-\mathrm{Fe}-\mathrm{Mo} \\
,\end{array}$} & \multirow{2}{*}{$\begin{array}{l}\text { o } 1 \\
2\end{array}$} \\
\hline$"$ & 2 & 7.16 & & & \\
\hline " & 3 & 9.57 & \multirow{3}{*}{9.72} & \multirow{3}{*}{ " } & 3 \\
\hline " & 4 & 9.62 & & & \multirow[t]{2}{*}{4} \\
\hline " & 5 & 9.96 & & & \\
\hline " & 6 & 10.3 & \multirow{4}{*}{10.7} & \multirow{4}{*}{$"$} & 5 \\
\hline " & 7 & 9.3 & & & 6 \\
\hline " & 8 & 10.1 & & & \multirow[t]{2}{*}{7} \\
\hline " & 9 & 12.9 & & & \\
\hline " & 10 & 14.6 & \multirow{7}{*}{14.2} & " & 8 \\
\hline " & 11 & 14.0 & & ", & 9 \\
\hline " & 12 & 13.2 & & " & 10 \\
\hline ", & 13 & 14.5 & & " & 11 \\
\hline " & 14 & 15.1 & & " & 12 \\
\hline$"$ & 15 & 14.5 & & " & 13 \\
\hline " & 16 & 13.3 & & & \\
\hline
\end{tabular}
entire concentration range at $1823 \mathrm{~K}$ are shown in Table 2 and in Fig. 4. The curve for $a_{\mathrm{Fe}}$ was determined by the following procedures.

In the region $0 \leq x_{\text {Mo }} \leq 0.35$ where the alloy is liquid,

\begin{tabular}{|c|c|c|c|c|}
\hline No. & & $x_{\mathrm{Mo}}$ & $a_{\mathrm{Fe}}$ & Phases \\
\hline $\mathrm{Fe}-\mathrm{Mo}$ & 6 & 0.096 & 0.897 & \multirow{12}{*}{$\begin{array}{l}\text { Fe liquid } \\
\text { solution }\end{array}$} \\
\hline$"$ & 2 & 0.154 & 0.810 & \\
\hline " & 4 & 0.200 & 0.800 & \\
\hline$"$ & 7 & 0.201 & 0.767 & \\
\hline " & 1 & 0.240 & 0.692 & \\
\hline \multirow[t]{2}{*}{ " } & 5 & 0.251 & 0.737 & \\
\hline & 9 & 0.254 & 0.741 & \\
\hline$"$ & 3 & 0.300 & 0.690 & \\
\hline$"$ & 8 & 0.302 & 0.673 & \\
\hline \multirow{2}{*}{\multicolumn{2}{|c|}{$\begin{array}{r}\Rightarrow \quad 10 \\
\text { Ag-Fe-Mo } 7\end{array}$}} & 0.333 & 0.677 & \\
\hline & & 0.339 & 0.652 & \\
\hline$"$ & 2 & 0.348 & 0.652 & \\
\hline \multirow{2}{*}{$\begin{array}{l}\text { " } \\
\text { " }\end{array}$} & 10 & 0.434 & 0.621 & \multirow{3}{*}{$\begin{array}{l}\text { Fe liquid } \\
\text { solution }+\sigma\end{array}$} \\
\hline & 11 & 0.434 & 0.656 & \\
\hline$"$ & 13 & 0.434 & $0.528^{*}$ & \\
\hline " & 8 & 0.556 & 0.585 & \multirow{5}{*}{$\begin{array}{l}\sigma+\text { Mo } \\
\text { solid solution }\end{array}$} \\
\hline$"$ & 9 & 0.613 & 0.552 & \\
\hline " & 12 & 0.666 & 0.526 & \\
\hline " & 4 & 0.778 & 0.556 & \\
\hline$"$ & 6 & 0.793 & 0.538 & \\
\hline \multirow{3}{*}{$"$} & 3 & 0.842 & 0.518 & \multirow{3}{*}{$\begin{array}{l}\text { Mo solid } \\
\text { solution }\end{array}$} \\
\hline & 1 & 0.912 & 0.360 & \\
\hline & 5 & 0.912 & 0.383 & \\
\hline
\end{tabular}
the following equation was obtained by the multiple regression analysis applied to the plots shown in Fig. 5. In Fig. 5, $\ln \gamma_{\mathrm{Fe}}$ is plotted against $x_{\mathrm{Mo}}$.

$$
\ln \gamma_{\mathrm{Fe}}=-2.0_{4} x_{\mathrm{Mo}}^{2}+6.0 x_{\mathrm{Mo}}^{3} \quad\left(0 \leq x_{\mathrm{Mo}} \leq 0.35\right)
$$

Standard deviations of the coefficients of each term
Table 1. Values of $\lambda$ in Eq. (7).

$T_{\text {Ag }}=1227 \mathrm{~K}$ for $\mathrm{Ag}-\mathrm{Fe} 1 \sim 5$

$T_{\mathrm{Ag}}=1234 \mathrm{~K}$ for $\mathrm{Ag}-\mathrm{Fe} 6 \sim 16$

Table 2. Result of activity measurements at $1823 \mathrm{~K}$.

* This value was not used in the following calculation of the value for $a_{\mathrm{Fe}}$ in the $\mathrm{Fe}(l)+\sigma$ phase region, because of its unreasonably low value.

in the right hand side of the above equation are \pm 0.7 and \pm 2.2 , respectively. The higher order terms are neglected because of the error in the $\gamma_{\mathrm{Fe}}$ measurement.

The region, $0.35 \leq x_{\mathrm{Mo}_{\mathrm{O}}} \leq 0.484$ is the liquid- $\sigma$ two 


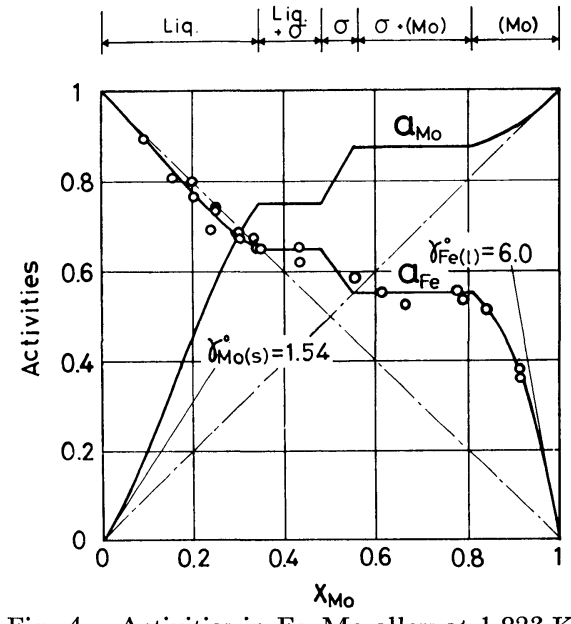

Fig. 4. Activities in Fe-Mo alloy at $1823 \mathrm{~K}$.

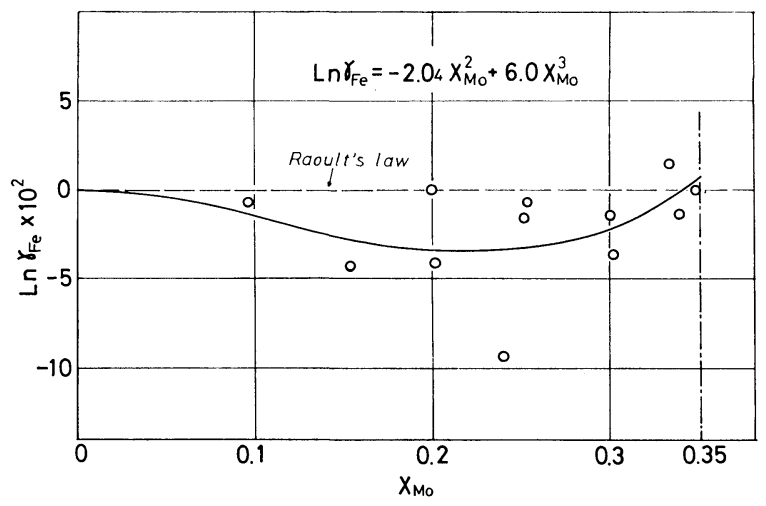

Fig. 5. The relation between $x_{\text {Mo }}$ and $\ln \gamma_{\mathrm{Fe}}$.

phase region. The average value of $a_{\mathrm{Fe}}$ from runs $\mathrm{Ag}-\mathrm{Fe}-\mathrm{Mo}$ 2, 7, 10 and 11 together with the extrapolation of $a_{\mathrm{Fe}}$ in the liquid phase region give a value for $a_{\mathrm{Fe}}$ in the liquid- $\sigma$ two phase region.

$$
a_{\mathrm{Fe}}=0.645 \pm 0.009 \quad \text { (liquid }+\sigma \text { ). }
$$

The standard deviation was calculated by the Eq. (30) in Section IV. 2.

The region, $0.554 \leq x_{\mathrm{Mo}} \leq 0.810$ is two phase region of $\sigma$-phase and the solid solution of Mo, (Mo). The average value of $a_{\mathrm{Fe}}$ in this region is

$$
a_{\mathrm{Fe}}=0.551 \pm 0.008 \quad(\sigma+(\mathrm{Mo}))
$$

The region, $0.484 \leq x_{\mathrm{Mo}} \leq 0.554$ is $\sigma$ phase region. As no measurements were carried out in this region, a linear change was assumed for $a_{\mathrm{Fe}}$.

$$
a_{\mathrm{Fe}}=-1.343 x_{\mathrm{Mo}}+1.295 \quad\left(0.484 \leq x_{\mathrm{Mo}_{0}} \leq 0.554\right) \ldots
$$

The region, $0.810 \leq x_{\mathrm{MO}} \leq 1$ is Mo solid solution. The Darken's quadratic formalism was applied to the experimental results to give the following expression.

$$
\ln \gamma_{\mathrm{Fe}}=2.14 x_{\mathrm{MO}}^{2}-0.34
$$

So far, the $\sigma$-phase in the Fe-Mo alloy system has been known to decompose at $1815 \mathrm{~K}^{12)}$ As reported, ${ }^{13)}$ the existence of the $\sigma$-phase at $1823 \mathrm{~K}$ was confirmed by the characteristic behavior of the ion intensity and by the microscopic study. The phase
Table 3. The composition of coexisting phases in the $\mathrm{Fe}-\mathrm{Mo}$ system at $1823 \mathrm{~K}$.

\begin{tabular}{c|c}
\hline Phases in equilibrium & $x_{\text {Mo }}$ of each phase in equilibrium \\
\hline Fe liquid solution $+\sigma$ & $\begin{array}{l}x_{\mathrm{Mo}} \text { (liquid solution) }=0.35 \\
x_{\mathrm{Mo}}(\sigma)=0.484\end{array}$ \\
\hline$\sigma+$ Mo solid solution & $\begin{array}{l}x_{\mathrm{Mo}}(\sigma)=0.554 \\
x_{\mathrm{Mo}} \text { (solid solution) }=0.810\end{array}$ \\
\hline
\end{tabular}

boundraies at $1823 \mathrm{~K}$ were determined through the microscopic examination and the EPMA analysis of the heat treated samples. The results are shown in Table 3.

The values for $\gamma_{\mathrm{Mo}}$ and $a_{\mathrm{Mo}}$ were calculated from Eqs. (11) to (15) by the use of the Gibbs-Duhem equation.

$$
\begin{aligned}
& \ln \gamma_{\mathrm{Mo}}=0.435+4.0_{8} x_{\mathrm{Mo}}-11.0 x_{\mathrm{Mo}}^{2}+6.0 x_{\mathrm{Mo}}^{3} \\
& \text { (Fe liq. solun.) } \\
& a_{\mathrm{Mo}}=0.757 \quad\left(0.35 \leq x_{\mathrm{Mo}} \leq 0.484\right) \\
& a_{\mathrm{Mo}}=1.686 x_{\mathrm{Mo}}-0.059 \quad(\sigma \text { phase }) \\
& a_{\mathrm{Mo}}=0.875 \quad\left(0.554 \leq x_{\mathrm{Mo}} \leq 0.810\right) \\
& \ln \gamma_{\text {Mo }}=2.14\left(1-x_{\text {Mo }}\right)^{2} \quad((\mathrm{Mo}) \text { solid solun. }) . .
\end{aligned}
$$

For brevity's sake, linear behavior was assumed for $a_{\mathrm{Mo}}$ in the $\sigma$ phase.

Activity curves for $\mathrm{Fe}$ and $\mathrm{Mo}$ and $\gamma^{\circ}$ are shown in Fig. 4. Values for activity, activity coefficient and partial molar free energy of Fe-Mo binary alloy at $1823 \mathrm{~K}$ are shown in Table 4. The calculation of the confidence limits attached to each figure in the Table 4 is given in Section IV. 2. The standard state for $a_{\mathrm{Fe}}$ is liquid $\mathrm{Fe}$ and that for $a_{\mathrm{Mo}}$ is solid Mo. The necessary data to convert these standard states to solid $\mathrm{Fe}$ and liquid Mo, respectively are also given in Table 4.

Nesmeyanov ${ }^{14)}$ who measured the activities of solid $\mathrm{Fe}-\mathrm{Mo}$ alloy at low Mo concentration within $\gamma$-loop, reported that remarkable negative deviation of $a_{\mathrm{Fe}}$ from the Raoults' law was observed below $1 \mathrm{wt} \%$ Mo. Although slight, the same tendency as in the solid was observed in the liquid alloy.

The interaction parameter of Mo in the region of $0 \leq x_{\mathrm{MO}_{\mathrm{O}}} \leq 0.35$ was calculated from Eq. (16) as follows.

$$
\varepsilon_{\mathrm{MO}}^{(\mathrm{MoO})}=4.1( \pm 1.4) \text { and } \varepsilon_{\mathrm{Mo}}^{(\mathrm{MO})^{2}}=-11.0( \pm 4.1)
$$

where,

$$
\varepsilon_{\mathrm{MO}}^{(\mathrm{Mo})^{n}}=(1 / n !)\left(\partial^{n} \ln \gamma_{\mathrm{Mo}} / \partial x_{\mathrm{Mo}}^{n}\right)_{x_{\mathrm{MO}} \rightarrow 0}
$$

The limits of confidence are expressed by the standard deviation for coefficients in Eq. (16). The interaction parameter $e_{\mathbb{H o}_{0}}^{\left(M 0_{0}\right)}$ based on the weight percent is defined as follows.

$$
e_{\mathrm{Mo}}^{(\mathrm{Mo})^{n}}=(1 / n !)\left(\partial^{n} \log f_{\text {Mo }} / \partial \% \mathrm{Mo}^{n}\right)_{\% \mathrm{Mo} \rightarrow 0}
$$

where $f_{\text {Mo }}$ is the activity coefficient where the hypothetical Henrian $1 \mathrm{wt} \%$ was chosen as the standard state. There is the following relation between $\varepsilon_{\mathrm{MIO}}^{(\mathrm{MO})} n$ and $e_{\mathrm{MO}}^{(\mathrm{MO})} n_{15}$, 
Table 4. Partial molar quantities of Fe-Mo alloys at $1823 \mathrm{~K}$.

\begin{tabular}{|c|c|c|c|c|c|c|c|c|c|}
\hline \multirow{2}{*}{$x_{\mathrm{Mo}}$} & \multirow{2}{*}{ Phase } & \multicolumn{4}{|c|}{$\begin{array}{c}\mathrm{Fe} \text { component } \\
\mathrm{Fe}(l)=\underline{\mathrm{Fe}} \text { (in alloy) }\end{array}$} & \multicolumn{4}{|c|}{$\begin{array}{c}\text { Mo component } \\
\operatorname{Mo}(s)=\underline{\text { Mo }} \text { (in alloy) }\end{array}$} \\
\hline & & $a_{\mathrm{Fe}}$ & $\gamma_{\mathrm{Fe}}$ & $\begin{array}{c}G_{\mathrm{Fe}}^{M} \\
(\mathrm{~kJ} / \mathrm{g} \text {-atom) }\end{array}$ & $\begin{array}{c}G_{\mathrm{Fe}}^{E} \\
(\mathrm{~kJ} / \mathrm{g} \text {-atom })\end{array}$ & $a_{\mathrm{Mo}}$ & $\gamma_{\text {Mo }}$ & $\begin{array}{c}G_{\mathrm{Mo}}^{M} \\
(\mathrm{~kJ} / \mathrm{g}-\mathrm{atom})\end{array}$ & $\begin{array}{c}G_{\mathrm{Mo}}^{E} \\
(\mathrm{~kJ} / \mathrm{g}-\text { atom })\end{array}$ \\
\hline 0 & \multirow{6}{*}{$\begin{array}{c}\text { Fe } \\
\text { liquid } \\
\text { solution }\end{array}$} & 1 & 1 & 0 & 0 & 0 & $\begin{array}{c}1.54 \\
\left(\begin{array}{c}+0.26 \\
-0.21\end{array}\right)\end{array}$ & $-\infty$ & $\begin{array}{r}6.6 \\
( \pm 2.3)\end{array}$ \\
\hline 0.1 & & 0.887 & 0.986 & -1.82 & -0.22 & 0.209 & 2.09 & -23.7 & 11.2 \\
\hline 0.2 & & $\begin{array}{r}0.774 \\
( \pm 0.008)\end{array}$ & $\begin{array}{r}0.967 \\
( \pm 0.009)\end{array}$ & $\begin{array}{c}-3.89 \\
( \pm 0.15)\end{array}$ & $\begin{array}{c}-0.51 \\
( \pm 0.15)\end{array}$ & $\begin{array}{r}0.472 \\
( \pm 0.012)\end{array}$ & $\begin{array}{r}2.36 \\
( \pm 0.06)\end{array}$ & $\begin{array}{l}-11.37 \\
\left(\begin{array}{l}+0.40 \\
-0.35\end{array}\right)\end{array}$ & $\begin{array}{c}13.02 \\
\left(\begin{array}{c}+0.40 \\
-0.35\end{array}\right)\end{array}$ \\
\hline 0.3 & & 0.685 & 0.979 & -5.73 & -0.33 & 0.689 & 2.296 & -5.65 & 12.59 \\
\hline \multirow[t]{2}{*}{0.35} & & 0.645 & 0.993 & -6.64 & -0.11 & 0.757 & 2.163 & -4.22 & 11.69 \\
\hline & & $( \pm 0.009)$ & $( \pm 0.013)$ & $\left(\begin{array}{l}+0.20 \\
-0.22\end{array}\right)$ & $\left(\begin{array}{l}+0.20 \\
-0.22\end{array}\right)$ & $\left(\begin{array}{l}+0.016 \\
-0.014\end{array}\right)$ & $\left(\begin{array}{l}+0.045 \\
-0.041\end{array}\right)$ & $\left(\begin{array}{l}+0.32 \\
-0.28\end{array}\right)$ & $\left(\begin{array}{l}+0.32 \\
-0.28\end{array}\right)$ \\
\hline 0.484 & \multirow{3}{*}{$\sigma$} & 0.645 & 1.250 & -6.64 & 3.39 & 0.757 & 1.564 & -4.22 & 6.78 \\
\hline 0.50 & & 0.624 & 1.247 & -7.16 & 3.35 & 0.784 & 1.568 & -3.69 & 6.82 \\
\hline 0.554 & & 0.551 & 1.236 & -9.03 & 3.22 & 0.875 & 1.579 & -2.02 & 6.93 \\
\hline \multirow[t]{2}{*}{0.81} & \multirow{4}{*}{$\begin{array}{c}\text { Mo } \\
\text { solid } \\
\text { solution }\end{array}$} & 0.551 & 2.90 & -9.03 & 16.13 & 0.875 & 1.080 & -2.02 & 1.17 \\
\hline & & $( \pm 0.008)$ & $( \pm 0.05)$ & $\left(\begin{array}{l}+0.17 \\
-0.27\end{array}\right)$ & $\left(\begin{array}{l}+0.17 \\
-0.27\end{array}\right)$ & $\left(\begin{array}{l}+0.017 \\
-0.014\end{array}\right)$ & $\left(\begin{array}{l}+0.021 \\
-0.018\end{array}\right)$ & $\left(\begin{array}{l}+0.29 \\
-0.25\end{array}\right)$ & $\left(\begin{array}{l}+0.29 \\
-0.25\end{array}\right)$ \\
\hline 0.90 & & 0.403 & 4.03 & -13.8 & 21.1 & 0.919 & 1.022 & -1.27 & 0.32 \\
\hline 1 & & 0 & $\begin{array}{r}6.0 \\
( \pm 1.1)\end{array}$ & $-\infty$ & $\begin{array}{r}27.3 \\
( \pm 2.7)\end{array}$ & 1 & 1 & 0 & 0 \\
\hline
\end{tabular}

$a_{\mathrm{Fe}}:$ measured; $a_{\mathrm{Mo}}$ : calculated by the Gibbs-Duhem equation

Data for conversion of standard states: $\mathrm{Fe}: \Delta H^{m}=15.1 \mathrm{~kJ} / \mathrm{g}$-atom*; $T_{m}=1809 \mathrm{~K}^{11)}$ (*this study)

Mo: $\Delta H^{m}=7777( \pm 1000) \mathrm{cal} / \mathrm{g}$-atom ${ }^{11)} ; \quad T_{m}=2890( \pm 5) \mathrm{K}$; $=32.54 \mathrm{~kJ} / \mathrm{g}$-atom

$$
\begin{aligned}
& e_{\mathrm{Mo}}^{(\mathrm{Mo})^{n}}=\frac{1}{2.303 \times 10^{2 n}}\left\{\sum_{k=0}^{n-1}\left(\frac{55.85}{95.94}\right)^{n-k}\right. \\
& \left(1-\frac{55.85}{95.94}\right)^{k} \cdot{ }_{n-1} c_{k} \cdot \varepsilon_{\mathrm{Mo}}^{(\mathrm{Mo})}{ }^{n-k} \\
& \left.+\frac{1}{n}\left(1-\frac{55.85}{95.94}\right)^{n}\right\}
\end{aligned}
$$

By inserting the values for $\varepsilon_{\mathrm{MO}}^{(\mathrm{Mo})}$ and $\varepsilon_{\mathrm{Mo}}^{(\mathrm{MO}) 2}$, the following values were obtained.

$$
\begin{aligned}
& e_{\mathrm{Mo}}^{(\mathrm{Mo})}=1.21 \times 10^{-2}\left( \pm 0.35 \times 10^{-2}\right) \\
& e_{\mathrm{Mo}}^{(\mathrm{Mo})^{2}}=-1.1 \times 10^{-4}\left( \pm 0.8 \times 10^{-4}\right)
\end{aligned}
$$

The change in the free energy with the conversion of the standard state from pure solid Mo to hypothetical Henrian $1 \mathrm{wt} \%$ in liquid $\mathrm{Fe}$ at $1823 \mathrm{~K}$,

$$
\mathrm{Mo}(s)=\underline{\mathrm{Mo}} \quad(1 \mathrm{wt} \% \text { in liq. } \mathrm{Fe})
$$

is given by

$$
\begin{aligned}
\Delta G_{1823}^{\circ} & =R \cdot 1823 \ln \left(\gamma_{M o}^{\circ}(s) \cdot 0.5585 / 95.94\right) \\
& =-71.5( \pm 2.8) \mathrm{kJ} / \mathrm{g} \text {-atom } \\
& =-17.1( \pm 0.7) \mathrm{kcal} / \mathrm{g}-\text { atom }
\end{aligned}
$$

where the value for $\gamma_{\text {Mo }}^{\circ}(s)$ is given in Table 4. Raoultian activity coefficient of Mo in liquid solution was calculated by the use of the melting temperature and the heat of melting of Mo.

$$
\gamma_{\text {Mo }}^{\circ}(l)=0.70\left(\begin{array}{l}
+0.39 \\
-0.37
\end{array}\right)
$$

By using $\gamma_{\mathrm{Mo}}^{\circ}(l), \Delta G_{1823}^{\circ}$ is rewritten as,

$$
\begin{aligned}
\Delta G_{1823}^{\circ}= & \Delta H_{\mathrm{Mo}}^{m}\left(T_{m}-1823\right) / T_{m} \\
& +R \cdot 1823 \ln \left(\gamma_{\mathrm{Mo}}^{\circ}(l) 0.5585 / 95.94\right)
\end{aligned}
$$

As the first approximation, $R T \ln \gamma_{\text {Mo }}^{\circ}(l)$ may be regarded as constant, hence the temperature dependence of $\Delta G^{\circ}$ for the reaction (24) is given as

$$
\begin{aligned}
\Delta G^{\circ} & =27100-54.1 T\left(\begin{array}{l}
+9900 \\
-9500
\end{array}\right) \mathrm{J} / \mathrm{g} \text {-atom } \\
& =6500-12.92 T\left(\begin{array}{l}
+2400 \\
-2300
\end{array}\right) \mathrm{cal} / \mathrm{g} \text {-atom } \ldots
\end{aligned}
$$

\section{Discussion}

\section{Heats of Sublimation and Vaporization of $\mathrm{Fe}$}

The heats of sublimation and vaporization have been measured by several authors. Along with their results, present results are shown in Table 5 . The heat of sublimation of $\alpha$-Fe at $298.15 \mathrm{~K}, \Delta H^{s}(\alpha)_{298}$ is calculated from the present result for heat of sublimation of $\delta$-Fe, $\Delta H^{s}(\delta)$ at mean temperature of $1737 \mathrm{~K}$ and heat capacity of $\mathrm{Fe}^{11)}$

$$
\begin{aligned}
\Delta H^{s}(\alpha)_{298} & =414 \quad \mathrm{~kJ} / \mathrm{g} \text {-atom } \\
& =99.0 \quad \mathrm{kcal} / \mathrm{g} \text {-atom }
\end{aligned}
$$

In the present experiment, the value for $\Delta H^{s}(\delta)$ was determined from the ion intensities of $\mathrm{Fe}$ at $A_{4}$ point and melting point and therefore depends on the values assigned to these temperatures. Values 
Table 5. Heats of sublimation and vaporization of iron.

\begin{tabular}{|c|c|c|}
\hline Investigators & $\begin{array}{l}\Delta H^{v} \text { or } \Delta H^{s} \\
\text { (kcal/g-atom) }\end{array}$ & $\begin{array}{l}\text { Temperature range } \\
\text { of measurements }\end{array}$ \\
\hline R. B. Resse et $\left.a l^{3}{ }^{3}\right)$ & $91.3 \pm 2.2$ & mean $1898 \mathrm{~K}$ \\
\hline \multirow{2}{*}{$\begin{array}{l}\text { S. W. Gilby and } \\
\text { G. R. St. Pierre }\end{array}$} & 93.3 & $1667 \sim 1809 \mathrm{~K}$ \\
\hline & 91.4 & $1809 \sim 1953 \mathrm{~K}$ \\
\hline $\begin{array}{l}\text { E. Kato and } \\
\text { T. Furukawa }{ }^{17)}\end{array}$ & 93.9 & $1813 \sim 1873 \mathrm{~K}$ \\
\hline \multirow{2}{*}{ Selected values ${ }^{11)}$} & 94.0 & $1737 \mathrm{~K}$ \\
\hline & 90.2 & $1840 \mathrm{~K}$ \\
\hline \multirow{2}{*}{ This study } & 93.7 & $1665 \sim 1809 \mathrm{~K}$ \\
\hline & 90.1 & $1809 \sim 187[3 \mathrm{~K}$ \\
\hline
\end{tabular}

$1665 \mathrm{~K}$ and $1809 \mathrm{~K}$ were adopted in this study. Values for $A_{4}$ point reported in the last thirty years are in the range of $1664 \sim 1673 \mathrm{~K}^{18-20)}$ and those for m.p., $1806 \sim 1809 \mathrm{~K} . .^{18,19,21)} \quad$ Calculation using these values for $A_{4}$ point and m.p. gives the values from 93.0 to $101.5 \mathrm{kcal} / \mathrm{g}$-atom for $\Delta H^{s}(\delta)$. The above obtained value for $\Delta H^{s}(\alpha)_{298}$ agrees well with that calculated from the heat of vaporization determined at mean temperature of $1841 \mathrm{~K}$ in the present study and also agrees well with the selected value 99300 $( \pm 300) \mathrm{cal} / \mathrm{g}$-atom. ${ }^{11)}$

\section{Estimation of the Confidence Limit}

The limit of confidence of $a_{\mathrm{Fe}}$ and $\gamma_{\mathrm{Fe}}$ is estimated as follows.

The limit of confidence of $\gamma_{\mathrm{Fe}}$ in the region of $0 \leq$ $x_{\mathrm{Mo}} \leq 0.35$ is calculated from the standard deviations for Eq. (11).

$$
\sigma_{\ln _{\gamma_{\mathrm{Fe}}}}=\sqrt{0.49 x_{\mathrm{Mo}}^{4}-3.1 x_{\mathrm{Mo}}^{5}+5.0 x_{\mathrm{Mo}}^{6}}
$$

In the region of $0.35 \leq x_{\mathrm{M}_{0}} \leq 1$, the limit of confidence is estimated by the use of the coefficient of variation, C.V., since C.V. may be regarded as constant in this region. The value for C.V. of $a_{\mathrm{Fe}}$ is calculated through Eq. (28) by the use of data in regions, $0.35 \leq$ $x_{\mathrm{Mo}_{\mathrm{o}}} \leq 0.484$ and $0.554 \leq x_{\mathrm{Mo}_{\mathrm{o}}} \leq 0.810$. For the calculation of C.V., data from runs $\mathrm{Ag}-\mathrm{Fe}-\mathrm{Mo} 2$ and 7 are also adopted.

$$
\begin{aligned}
& \text { C.V. }=\left(1 / \bar{a}_{\mathrm{Fe}}\right) \sqrt{\left(\sum\left(a_{\mathrm{Fe}}-\bar{a}_{\mathrm{Fe}}\right)^{2} /\left(n_{t}-1\right)\right.} \\
& =\sqrt{\frac{\sum\left(\frac{a_{\mathrm{Fe}}-0.645}{0.645}\right)^{2}+\sum\left(\frac{a_{\mathrm{Fe}}-0.551}{0.551}\right)^{2}}{9-1}} \\
& =0.032
\end{aligned}
$$

where $n_{t}$ is the total number of measurements and $\tilde{a}_{\mathrm{Fe}}$ is the mean value of $a_{\mathrm{Fe}}$ in each two phase region. As the following equation holds,

$$
\sigma a_{\mathrm{Fe}}=(G . V .) \cdot \overline{\mathrm{r}}_{\mathrm{Fe}}
$$

the standard deviation $\sigma_{\bar{a}_{\mathrm{Fe}}}$ is calculated through Eq. (30),

$$
\sigma_{\bar{a}_{\mathrm{Fe}}}=\frac{\sigma a_{\mathrm{Fe}}}{\sqrt{n}}=(G . V .) \bar{a}_{\mathrm{Fe}} / \sqrt{ } n
$$

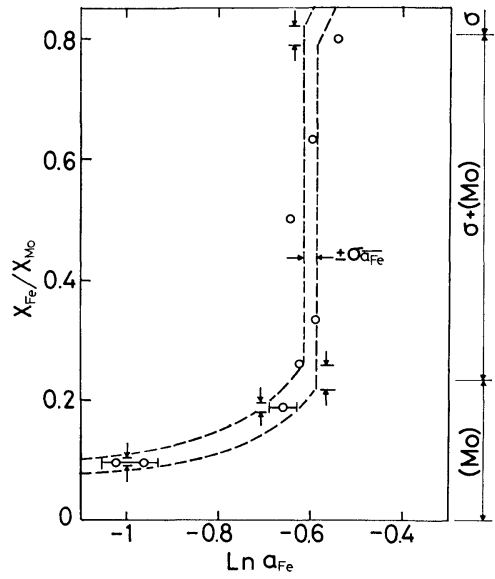

Fig. 6. Estimation of experimental errors of $a_{\mathrm{Fe}}$ and $a_{\mathrm{Mo}}$.

where $n$ is the number of measurements in each region.

The value for C.V. calculated through Eq. (28) was used to determine the value for $\sigma a_{\mathrm{Fe}}$ within the region $0.81 \leq x_{\mathrm{M}_{0}} \leq 1$, for only a few measurements were carried out in this region. Combination of these limits of confidence with the error in the determination of composition of alloy ( $\pm 0.5 \%$ ) gives the upper and lower limit of confidence for the activity curve as shown in Fig. 6.

As no measurements were carried out in the $\sigma$ phase region, the limit of confidence of $a_{\mathrm{Fe}}$ in both of the two phase regions adjacent to the $\sigma$-phase are tied linearly to give the limit of the confidence of $a_{\mathrm{Fe}}$ in $\sigma$-phase.

Curves indicating upper and lower limit of confidence of $a_{\mathrm{Fe}}$ were integrated according to the GibbsDuhem equation to give the limit of confidence of $a_{\mathrm{Mo}}$ and $\gamma_{\mathrm{Mo}}$.

The limits of confidence of thermodynamic properties listed in Table 4 are calculated from the limit of confidence of activities.

\section{Conclusion}

The heat of vaporization and sublimation of $\mathrm{Fe}$ and activities of $\mathrm{Fe}-\mathrm{Mo}$ binary alloy at $1823 \mathrm{~K}$ were determined by the use of Knudsen cell-mass spectrometry.

In the second law determination of the heat of sublimation of $\delta$-Fe, ion intensities at $A_{4}$ point and melting point were utilized. The heat of melting was obtained as the difference between heats of sublimation and vaporization. The heat of sublimation of $\alpha$ $\mathrm{Fe}$ at $298.15 \mathrm{~K}$ and the heat of melting at $1809 \mathrm{~K}$ are

$$
\begin{aligned}
& \Delta H^{s}(\alpha)_{298}=414 \mathrm{~kJ} / \mathrm{g} \text {-atom, } \\
& \Delta H_{1809}^{m}=15.1 \mathrm{~kJ} / \mathrm{g} \text {-atom. }
\end{aligned}
$$

In the measurement of activity, pure $\mathrm{Fe}$ or $\mathrm{Ag}$ was used as the internal standard material. Activities and thermodynamic properties of the system at $1823 \mathrm{~K}$ for the entire concentration range are shown in Fig. 4 and Table 4. Activity coefficients at infinitely dilute solution are given as follows:

$$
\begin{aligned}
& \gamma_{\text {Mo }}^{\circ}(s)=1.54\left(\begin{array}{l}
+0.32 \\
-0.26
\end{array}\right), \quad \gamma_{\text {Mo }}^{\circ}(l)=0.70\left(\begin{array}{l}
+0.39 \\
-0.37
\end{array}\right) \\
& \gamma_{\mathrm{F}_{0}}^{\circ}(l)=6.0( \pm 1.1)
\end{aligned}
$$


Interaction parameters of the activity coefficient are as follows.

$$
\begin{aligned}
& \varepsilon_{\mathrm{Mo}}^{(\mathrm{Mo})}=4.1( \pm 1.4) \\
& \varepsilon_{\mathrm{Mo}}^{(\mathrm{Mo})^{2}}=-11.0( \pm 4.1) \\
& e_{\mathrm{Mo}}^{(\mathrm{Mo})}=1.21 \times 10^{-2}\left( \pm 0.35 \times 10^{-2}\right) \\
& e_{\mathrm{Mo}}^{(\mathrm{Mo})^{2}}=-1.1 \times 10^{-4}\left( \pm 0.8 \times 10^{-4}\right)
\end{aligned}
$$

The standard free energy change $\Delta G^{\circ}$ for the reaction

$$
\begin{aligned}
\operatorname{Mo}(s)= & \text { Mo (hypothetical Henrian } 1 \mathrm{wt} \% \text { in } \\
& \text { liquid Fe) }
\end{aligned}
$$

is calculated by the use of the regular solution assumption,

$$
\Delta G^{\circ}=27100-54.1 T\left(\begin{array}{l}
+9900 \\
-9500
\end{array}\right) \mathrm{J} / \text { g-atom } .
$$

\section{REFERENCES}

1) S. Nobori, K. Saito, Y. Iguchi and T. Fuwa: Tetsu-toHagané, 62 (1976), S558.

2) E. S. Filippov and S. I. Filippov: Izv. VUZov, Cher. Met., (1967), No. 1, 9.

3) R. B. Reese, R. A. Rapp and G. R. St. Pierre: Trans. Met. Soc. AIME, 242 (1968), 1719.

4) R. W. Jones, F. E. Stafford and D. H. Whitemore: Met. Trans., 1 (1970), 403.
5) J. V. Hackworth, M. Hoch and H. L. Gegel: Met. Trans., 2 (1971), 1799.

6) J. Berkowitz and W. A. Chupka: Ann. N.Y. Acad. Sci., 79 (1960), 1073.

7) G. R. Belton and R. J. Fruehan: J. Phys. Chem., 71 (1967), 1403.

8) T. Saito, Y. Shiraishi and M. Ismail: Proc. 4th Int'l. Conf. Vac. Met., ISIJ, (1974), 39.

9) E. Ichise, K. Kitao and T. Mori: Tetsu-to-Hagané, 60 (1974), 2119.

10) E. Ichise, T. Yamauchi and T. Mori: Tetsu-to-Hagané, 63 (1977), 417.

11) R. Hultgren, D. D. Desai, D. T. Hawkins, M. Greiser, K. K. Kelley and D. D. Wagman: Selected Values of the Thermodynamic Properties of the Elements, ASM, (1973), 186 $\& 313$.

12) Metals Handbook, 8th ed., ASM, 8 (1973), 303.

13) Y. Ueshima, E. Ichise and T. Mori: Tetsu-to-Hagané, 65 (1979), S684.

14) A. N. Nesmeyanov and G. Trapp: Zhur. Fiz. Khim., 39 (1965), 356.

15) A. Morooka and T. Mori: private communication.

16) S. W. Gilby and G. R. St. Pierre: Trans. Met. Soc. AIME, 245 (1969), 1749.

17) E. Kato and T. Furukawa: Trans. Casting Research Laboratory, Waseda Univ., (1973), No. 27, 97.

18) C. Boulanger: Compt. Rend., 241 (1955), 1133.

19) J. R. Pattison and P. W. Willows: JISI, 183 (1956), 390.

20) W. A. Dench and O. Kubaschewski: JISI, 201 (1963), 140.

21) T. H. Schofield and A. E. Bacon: J. Inst. Metals, 82 (1953), 167. 